\title{
CARBOHYDRATES, PHENOLIC COMPOUNDS AND ANTIOXIDANT ACTIVITY IN PULP AND PEEL OF 15 BANANA CULTIVARS

\author{
CÉSAR FERNANDES AQUINO ${ }^{2}$, LUIZ CARLOS CHAMHUM SALOMÃO ${ }^{3}$, \\ SÔNIA MACHADO ROCHA RIBEIRO ${ }^{4}$, DALMO LOPES DE SIQUEIRA ${ }^{3}$, \\ PAULO ROBERTO CECON 5
}

\begin{abstract}
The aim of this study was to quantify and compare the levels of carbohydrates and phenolic compounds and the antioxidant activity in the pulp and peel of 15 banana cultivars in two ripening stages. Four bunches per cultivar were harvested in the pre-climacteric stage, six fruits were used by sample unit. Fruits were analyzed in the pre-climacteric stage and after ripening. Total, reducing and non-reducing soluble sugars, starch, phenolic compounds and antioxidant activity were evaluated. Cultivar and ripening stage influenced all characteristics analyzed. Unripe pulp and peel had small percentage of sugar, but high percentage of starch, especially 'Terrinha' and 'Marmelo' cultivars. AAB and ABB cultivars presented the highest percentages of starch, when compared to AA and AAA cultivars. For the phenolic compounds, the highest content was observed in ripe peel, followed by ripe pulp and unripe peel and pulp, highlighting 'Terrinha' cultivar in all parts and stages evaluated. The antioxidant potential was higher in ripe peel, followed by unripe peel, ripe and unripe pulp. Fruits of Terrinha, Marmelo, Maçã, Ouro and Caru-Verde cultivars showed the highest carbohydrate contents, and phenolic compounds or antioxidant activity, justifying future actions in the expansion of planting and consumption of these fruits.
\end{abstract}

Index terms: Musa spp.; soluble sugars, starch, free radical.

\section{CARBOIDRATOS, COMPOSTOS FENÓLICOS E ATIVIDADE ANTIOXIDANTE EM POLPAS E CASCAS DE 15 CULTIVARES DE BANANEIRA}

\begin{abstract}
RESUMO - Objetivou-se quantificar os teores de carboidratos, compostos fenólicos e a atividade antioxidante na polpa e na casca de bananas de 15 cultivares, em dois estádios de maturação. Foram colhidos quatro cachos por cultivar, na fase pré-climatérica, sendo utilizados seis frutos por unidade amostral. Os frutos foram analisados na fase pré-climatérica e após o amadurecimento. Foram avaliados os teores de açúcares solúveis totais, redutores e não redutores, amido, compostos fenólicos e a atividade antioxidante. A cultivar, bem como o estádio de maturação, influenciou todas as características avaliadas. A polpa e a casca verdes apresentaram pequena porcentagem de açúcares, porém alta porcentagem de amido, com destaque para a 'Terrinha' e a 'Marmelo'. As cultivares dos grupos genômicos AAB e ABB apresentaram maior porcentagem de amido, em comparação com as cultivares dos grupos AA e AAA. O maior teor de compostos fenólicos foi observado em casca madura, seguida pela polpa madura, casca e polpa verdes, destacando-se a 'Terrinha', em todas as partes e nos estádios avaliados. O potencial antioxidante foi maior na casca madura, seguida pela casca verde, polpas madura e verde. Frutos das cultivares Terrinha, Marmelo, Maçã, Ouro e CaruVerde destacam-se quanto aos maiores teores de carboidratos, compostos fenólicos e/ou ação antioxidante, justificando futuras ações na expansão do plantio e no consumo desses frutos.
\end{abstract}

Termos para indexação: Musa spp., açúcares solúveis, amido, radical livre.

\footnotetext{
1(Paper 124-15). Received May 11, 2015. Accepeted November 26, 2015.

${ }^{2}$ Agronomist, Post-Doctorate. Department of Plant Technology, UFV / Viçosa-MG. Scholarship (Fapemig / Capes). Email: cesarfernandesaquino@yahoo.com.br

${ }^{3}$ Agronomist, PhD. Department of Plant Technology, UFV / Viçosa-MG. Email: 1salomao@ufv.br, siqueira@ufv.br

${ }^{4}$ Nutritionist, PhD. Department of Nutrition and Health, UFV / Viçosa-MG. Email: sribeiro@ufv.br

${ }^{5}$ Agronomist, PhD. Department of Statistics, UFV / Viçosa-MG. Email: cecon@ufv.br.
} 


\section{INTRODUCTION}

Banana is an important fruit in several regions of the world due to its high nutritional value, being a relatively cheap product, and can be consumed far from the places where it is produced and is therefore accessible to populations in all regions and social classes. Banana peel is an individual, hygienic and easy-to-remove packaging, making handling easy and convenient. The absence of seeds and availability throughout the year also contribute to its acceptance (LICHTERBERG, 1999).

Usually, only ripe pulp is consumed due to its high sugar content and sensory aspects. However, the green fruit is also consumed in cooking dishes typical of some regions due to its high starch content. In addition, the incorporation of green fruit flour in some products, like biscuits, bread rich in fibers and edible films, is increasing. The consumption of green bananas (peel and pulp) is beneficial to human health due to the high content of resistant starch, which acts in the body as food fiber (RODRÍGUEZAMBRIZ et al., 2008; OLIVEIRA et al., 2015). Moreover, banana flour can be an important source of polyphenols, compounds considered natural antioxidants (VERGARA-VALENCIA et al., 2007).

In addition to the importance of carbohydrates, attention has been directed to the study of the antioxidant activity present in the most diverse fruits, including banana. The presence of antioxidant components such as phenolic compounds in the human diet is associated with protective effects in the prevention of some chronic-degenerative diseases related to oxidative stress, i.e., preventing the harmful action of free radicals on proteins, DNA and lipids (ISABELLE et al., 2010). In addition, antioxidant compounds have proven action on synergistic effects and protective properties against various degenerative diseases, including cancer, stroke, cardiovascular diseases, Parkinson's and Alzheimer's disease (ABDEL-HAMEED, 2009).

In literature, some studies have demonstrated the occurrence of phenolic compounds and antioxidant action in banana (PATTHAMAKANOKPORN et al., 2008; GONZÁLEZ-MONTELONGO et al., 2010; SULAIMAN et al., 2011; FATEMEH et al., 2012; SHIAN et al., 2012; REBELLO et al., 2014). Sulaiman et al. (2011) observed the total phenolic content of eight banana cultivars in Malaysia, ranging from 0.09 to $20.47 \mathrm{mg} \mathrm{GAE} \mathrm{/} 100 \mathrm{~g}$, respectively, in the pulp and peel, demonstrating the need for research with the peel of other banana cultivars. Shian et al. (2012) reported for 'Berangan' (AA), 'Mas' (AA) and 'Raja' (ABB) banana cultivars in Malaysia radical removal percentage varying from 3.2 to $63.1 \%$ in mature pulp, making imperative the evaluation of the pulp and peel at different ripening stages. However, these works were conducted with cultivars not planted and marketed in Brazil. In addition, they are mainly works with few cultivars conducted to evaluate fruits in only one ripening stage and, in general, only pulp is evaluated. Therefore, there are a large number of banana cultivars, especially in Brazil, that have not yet been studied for the quantification of carbohydrates, phenolic compounds and the evaluation of the antioxidant activity of fruits, in both pulp and peel, in different ripening stages.

Thus, the aim of this study was to quantify and compare the contents of carbohydrates, total phenolic compounds and antioxidant activity in fruit pulp and peel of 15 banana cultivars at two ripening stages.

\section{MATERIAL AND METHODS}

Bunches of 15 banana cultivars: Ouro (AA), Nanica (AAA), Nanicão (AAA), Caru-Verde (AAA), Caru-Roxa (AAA), Caipira (AAA), Prata (AAB), Prata-Anã (AAB), Maçã (AAB), Mysore (AAB), Pacovan (AAB), Terrinha (AAB), Marmelo (ABB), Prata-Graúda (AAAB) and Caju (genomic group not defined) were harvested in plants spaced $3.5 \mathrm{~m} \mathrm{x} 2.5$ $\mathrm{m}$, in an experimental orchard at the age of six at the Federal University of Viçosa, Viçosa, Minas Gerais, located at $20^{\circ} 45^{\prime} \mathrm{S}$ and $42^{\circ} 52^{\prime} \mathrm{W}$, and $648 \mathrm{~m}$ asl.

Bunches were harvested when the first signs of appearance of yellow color in fruit peel were observed. From each bunch, the second, third and fourth hands were removed and immediately transported to the Laboratory of Fruit Analysis, Federal University of Viçosa, where fruits were cut close to the cushion brooms, eliminating the damaged, diseased and malformed fruits. Fruits were then washed in running water and allowed to stand on absorbent paper for a few minutes to coagulate the latex. Then, 12 fruits at color stage 1 were selected (dark green peel coloration) (DADZIE; ORCHARD, 1997), six of which were immediately evaluated. The other six fruits were immersed in ethephon solution $\left(1.2 \mathrm{~g} \mathrm{~L}^{-1}\right)$ for eight minutes to standardize ripening. After drying in the air for 15 min, they were immersed in Prochloraz fungicidal solution $\left(0.49 \mathrm{~g} \mathrm{~L}^{-1}\right)$ for five minutes to prevent the development of post-harvest diseases. After this time, the six fruits were packed in plastic boxes and kept at room temperature until they reached color stage 6 (completely yellow peel) (DADZIE; ORCHARD, 1997), which occurred in four days.

The composite samples for pulp, green and 
mature peel were conditioned in aluminum wrap, identified, immediately submitted to freezing in liquid nitrogen and conditioned in ultra-freezer at -80 ${ }^{\circ} \mathrm{C}$ until the moment of analyses in order to minimize possible losses of evaluated compounds. Freezing was necessary according to the number of samples analyzed and the period required for collection of bunches.

The design was completely randomized, with 15 treatments (cultivars) and four replicates (bunches), with six fruits per sample unit. From each cultivar, unripe and ripe pulp and unripe and ripe peel were analyzed. Each part of the fruit, as well as each color stage, was considered as a distinct experiment, evaluating the following characteristics: total soluble sugars, reducing and non-reducing sugars, starch, total phenolic compounds and antioxidant potential.

Total soluble sugars, reducing sugars, nonreducing sugars and starch were extracted in 0.5 $\mathrm{g}$ samples of pulp and fruit peel of each cultivar at ripening stages 1 and 6 . Total soluble sugars, reducing sugars, non-reducing sugars were extracted with $80 \%$ hot ethanol (HODGE; HOFREITER, 1962). For starch, the residue from the alcoholic extractions was treated with $52 \%$ perchloric acid and water at a ratio of 1: 1.3 according to McCready et al. (1950), modified by Patel (1970). Extracts were stored in freezer at $-20^{\circ} \mathrm{C}$ until time of quantification.

Total soluble sugars and starch were determined by reaction with anthrone (9,10-dihydro-9-oxoanthracene), changing the reagent concentration to $0.1 \%$ in sulfuric acid $(28 \mathrm{~N})$. Absorbance at $620 \mathrm{~nm}$ was read in spectrophotometer. A standard curve with D-glucose at concentration from 0.02 to $0.1 \mathrm{mg} \mathrm{L}^{-1}$ was used for determination of sugars and starch. To calculate the starch content, the mass found for glucose was multiplied by 0.9 to obtain the starch mass.

The quantification of reducing sugars was performed by the method of Nelson (NELSON, 1944; SOMOGYI, 1952). Absorbance at $540 \mathrm{~nm}$ was read in spectrophotometer. A standard curve with D-glucose at concentration from 0.01 to $0.5 \mathrm{mg} \mathrm{L}^{-1}$ was used to determine reducing sugars. Non-reducing sugars were obtained by the difference between total soluble sugars and reducing sugars. The results for total soluble sugars, reducing sugars, non-reducing sugars and starch were expressed as a percentage based on the fresh matter of each part evaluated.

Unripe and ripe pulp and peel extracts containing the phenolic compounds were obtained according to Bloor (2001) with modifications. About $1 \mathrm{~g}$ of vegetable material was macerated in a mortar. Then, $20 \mathrm{~mL}$ of a methanol: water $(80: 20 \mathrm{v}$
/ v) mixture were added, leaving the system to stand for $16 \mathrm{~h}$. After this time, extracts were filtered and the solvents evaporated to dry, and the residue was re-suspended in $5 \mathrm{~mL}$ of methanol: water mixture $(80: 20 \mathrm{v} / \mathrm{v})$. An aliquot of this extract was used to quantify total phenols.

The total phenolic content was colorimetrically determined using the Folin-Ciocalteu reagent (Sigma-Aldrich, USA), according to Singleton et al. (1999). Aliquots of $0.5 \mathrm{~mL}$ methanolic extract were added to $0.5 \mathrm{~mL}$ Folin-Ciocalteu reagent $(20 \% \mathrm{v} /$ $\mathrm{v}$ ), followed by the immediate addition of $0.5 \mathrm{~mL}$ of aqueous sodium carbonate solution $(7.5 \%, \mathrm{w} / \mathrm{v})$. The mixture was stirred and allowed to stand for 30 min in the dark. Absorbance was read at $765 \mathrm{~nm}$ in spectrophotometer. A standard curve of gallic acid (Sigma-Aldrich, USA) ranging from 0.01 to 0.09 $\mathrm{mg} \mathrm{mL} \mathrm{m}^{-1}$ was used to estimate contents, which were expressed in milligrams of gallic acid equivalents (GAE) per $100 \mathrm{~g}$ of vegetal tissue (pulp and peel), based on the wet matter.

The capacity of free radical sequestration was evaluated with the DPPH (2,2-diphenyl-2picrylhydrazyl radical) test (Sigma-Aldrich, USA), according to Blois (1958). Aliquots of $0.5 \mathrm{~mL}$ of methanolic extracts of pulp and $0.25 \mathrm{~mL}$ of peel were mixed with $1.5 \mathrm{~mL}$ of $0.1 \mathrm{mM}$ DPPH methanolic solution. Subsequently, the mixture was stirred and left to stand in the dark for $30 \mathrm{~min}$ at $25^{\circ} \mathrm{C}$. Thereafter, the mixture absorbance was recorded at $517 \mathrm{~nm}$, and the results were expressed as percentage of radical removal.

Data of variables referring to the comparison among cultivars were submitted to analysis of variance and the means were grouped by the Scott-Knott criterion $(p<0.01)$, using the System for Statistical and Genetic Analysis - SAEG 9.1. Comparisons among fruit parts were made through descriptive statistics.

\section{RESULTS AND DISCUSSION}

For all variables analyzed, it was observed that the results are dependent on the part of the fruit being evaluated, the ripening stage and cultivar used.

\section{Carbohydrates in the pulp}

It was found in unripe pulp that the percentage of total soluble sugars (TSS) was less than $1 \%$, while the percentage of starch was generally higher than $20 \%$. The starch content in the unripe pulp is an important data due to the high percentage of resistant starch, providing beneficial effects on human health through the action in the human 
body as dietary fiber (RODRÍGUEZ-AMBRIZ et al., 2008); therefore, unripe pulp can be considered as an important functional food in the human diet (OLIVEIRA et al., 2015). 'Marmelo' and 'Terrinha' banana cultivars stood out with the highest starch content, and 'Caipira' banana cultivarshowed the lowest percentage. $\mathrm{AAB}$ and $\mathrm{ABB}$ cultivars showed higher starch content compared to AA and AAA cultivars (Table 1). According to Emaga et al. (2007), banana has high starch content in the unripe pulp and, even when ripe, it maintains the high content, requiring preparation such as cooking or frying for consumption. Leonel et al. (2011) observed, for TSS and reducing sugars (RS) in unripe pulp, similar percentages to those verified in this work. In addition, these authors also observed lower starch content in 'Caipira' banana cultivar and similar value in 'Marmelo' cultivar when evaluating eight banana cultivars.

In general, in unripe pulp, predominance of reducing sugars over non-reducing sugars in $\mathrm{AAB}$ and Prata-Graúda (AAAB) cultivars was observed, unlike the others, in which non-reducing sugars predominate (Table 1).

The carbohydrate composition of bananas changes considerably during ripening. Starch is the main component of unripe bananas. The average starch content decreases from 70 to $80 \%$ (dry matter basis) in the pre-climacteric period (before disaggregation) to less than $1 \%$ at the end of the climacteric period, while soluble sugars, mainly non-reducing sugars, accumulate more than $10 \%$ of the fresh fruit weight. The percentage of total soluble sugars can reach values of the order of $23 \%$ of the pulp fresh weight, indicating a high conversion rate (Table 1).

In all cultivars analyzed, there was an increase in the percentage of sugars in the pulp during fruit ripening due to the starch hydrolysis and consequent accumulation of sugars, a fundamental change in the organoleptic characteristics of fruits. The percentage of TSS varied significantly among cultivars, with averages of $10.9 \%$ and $23.06 \%$ for 'Prata-Anã' and 'Terrinha', respectively, and the average percentage of all cultivars was $19.50 \%$ (Table 1). Ouro, Nanica, Nanicão, Caru-Roxa, Prata, Prata-Anã, Mysore and Pacovan cultivars stood out with the highest TSS percentages, on average $22.31 \%$. On the other hand, in plantain-type 'Terrinha' and 'Marmelo' bananas, the average TSS percentage was only $11.2 \%$ and the starch content was 12.6 and $13.33 \%$, respectively, indicating lower starch conversion in TSS in these two cultivars.

For reducing sugars, 'Terrinha' and
'Marmelo' cultivars presented higher predominance of reducing sugars in relation to the non-reducing sugars. However, in 'Nanica', 'Caru-Verde', 'Caipira', 'Prata', 'Prata-Graúda' and 'Caju' cultivars, there was predominance of non-reducing sugars in relation to reducing sugars (Table 1). Jesus et al. (2004) observed, in 10 banana cultivars, significantly higher percentages of reducing sugars compared to non-reducing sugars.

'Marmelo' and 'Terrinha' cultivars, even in the ripe pulp, presented starch percentage, approximately three times higher than the general average, being common in plantain-type banana the maintenance of high starch content, even in ripe fruits (Table 1). With the exception of these two cultivars, the mean values are below those reported by Jesus et al. (2004). In these cultivars, it is evident that, even with presence of yellow peel, the pulp may not be completely ripe. According to Mota et al. (1997), the difference in residual starch contents in ripe pulp among cultivars is related to the structural differences of starch granules or to the enzymatic activity that degrades starch during ripening.

\section{Carbohydrates in the peel}

The TSS percentage in unripe peel was very low, less than half the average value found in unripe pulp, with percentages ranging from 0.14 to $0.23 \%$. Reducing sugars predominated over non-reducing sugars, except in 'Ouro' and 'Nanicão' cultivars. As for starch, the percentage ranged from 4.07 to $12.69 \%$ for 'Caipira' and 'Marmelo' cultivars, respectively (Table 2). With fruit ripening, 'Maçã' cultivar stood out with the highest TSS percentage in the ripe peel. In general, in cultivars with the presence of part of the M. balbisiana genome (B) and in the 'Caju' cultivar, predominance of reducing sugars over non-reducing sugars was observed, except for 'Maçã' and 'Terrinha' cultivars. Non-reducing sugars predominated in AA and AAA cultivars, with the exception of 'Caipira' cultivar. In ripe pulp, the starch content was also drastically reduced, compared to unripe peel; however, even ripe, 'Marmelo' and 'Terrinha' cultivars still showed higher starch percentage compared to the other cultivars (Table 2).

Emaga et al. (2007) investigated the effect of color stage and cultivars on the chemical composition of banana peels and plantain from Cameroon. These authors observed a reduction in the starch content from stage 1 to stage 5 (yellow peel with green ends) and 7 (yellow peel with some brown spots), while the soluble sugar content increased from stage 1 to stage 5 . However, for glucose and fructose content, there was an increase from stage 1 to stage 7 . Fruits 
from 'Caipira' (AAA) and 'Grande Naine' (AAA) cultivars presented the lowest starch content (dry matter basis) at stage 1 (14 and 11\%, respectively), compared to 'French Clair' (AAB), 'Big Ebanga' (AAB), 'Pelipita' (ABB) and 'CRBP039' (AAAB) cultivars, which respectively presented $35.4 ; 39.3$; 36.0 ; and $37.6 \%$ (dry matter basis). In bananas and plantain at stage 7 , the starch content ranged from 0.3 to $3.3 \%$, respectively.

The percentage of sugar is responsible for the degree of sweetness of banana and, when associated with acidity, is a measure correlated with the fruit flavor quality (CHITARRA; CHITARRA, 2005), which may influence the consumer's preference for one or the other cultivar. In addition to the importance of TSS in fruits for fresh consumption, it also plays a prominent role in industrial processing, since high TSS contents in the raw material imply lower sugar addition, shorter water evaporation time, lower energy consumption and higher product yield, resulting in greater processing economy (Silva et al., 2003).

Starch present in banana has great potential for industrial use due to its specific properties and low production cost due to the high pulp and unripe peel content and the possibility of using bananas unfit for fresh commercialization. Unripe banana pulp contains up to $70-80 \%$ starch by weight (dry matter basis), a percentage comparable to that of corn kernel endosperm and potato pulp, and can be applied in processed foods, pharmaceuticals, paper, plastic and other industrial sectors (ZHANG et al., 2005).

In addition, banana and plantain starch is known to have high percentage of resistant starch, with slow digestion and low glycemic index, being an important feature for incorporation in foods with "low levels" of carbohydrates (RODRÍGUEZ-AMBRIZ et al., 2008). Juarez-García et al. (2006) reported on unripe banana pulp meal (Musa paradisiaca L.) total starch content of $73.4 \%$, resistant starch of $17.5 \%$ and fibers of $14.5 \%$, dry matter basis. According to these authors, bread made from this flour has low glycemic index and high fiber content; therefore, can be used as food supplement by people with special low calorie requirements. Thus, unripe banana flour (pulp and peel) can be used as a functional ingredient in several foods, providing health benefits to humans because they play an important role in the prevention and treatment of obesity, atherosclerosis, coronary diseases, colorectal cancer and diabetes (JUAREZ -GARCÍA et al., 2006).

In view of these characteristics, the use of unripe banana (peel and pulp) with higher starch content or even fruits considered unfit for fresh consumption to obtain starch can provide a competitive product in the market, minimizing losses with the disposal of scraps at the time of harvest, sorting and packaging.

\section{Phenolic compounds in pulp and peel}

Unripe pulp presented the lowest content of phenolic compounds in comparison to the other parts, being on average 3.2 times smaller compared to ripe peel. 'Terrinha' (AAB) and 'Marmelo' (ABB) cultivars stood out with the highest content. With fruit ripening, there was an increase in the content of phenolic compounds in the ripe pulp, especially in 'Terrinha' and the 'Ouro' cultivars, with the highest levels. In addition, in the ripe pulp, the lowest content observed (42.39 mg GAE / $100 \mathrm{~g}$ ) is higher than the highest content (33.28 mg GAE / $100 \mathrm{~g}$ ) found in the unripe pulp (Table 3). The fact that the ripe pulp presents high content of phenolic compounds may be an additional stimulus to increase banana consumption, regardless of cultivar, due to the benefits of these antioxidant compounds.

For the unripe peel, 'Terrinha' cultivar also stood out with higher average, with contents of phenolic compounds approximately two times greater than that observed in 'Ouro' cultivar (AA). The highest levels of phenolic compounds were found in the ripe peel, with mean content of 3.19; 1.57 and 2.15 higher than the unripe pulp, ripe pulp and unripe peel, respectively. 'Terrinha' cultivar also stood out with content about two times higher than the content found of 'Marmelo' cultivar. Based on the average values of pulp and peel mean at both ripening stages, it was observed that these parts, when ripe, present approximately twice the content of phenolic compounds of the same parts when unripe (Table 3 ). The fact that 'Terrinha' cultivar present the highest content of phenolic compounds in pulp and peel in both ripening stages points to the need to increase the consumption of this cultivar by the population and, consequently, the planted area, due to the presence of antioxidant compounds.

Sulaiman et al. (2011) observed contents of phenolic compounds in Mas (AA), Kapas (AA), Berangan (AAA), Rastali (AAB), Raja (AAB), Nangka (AAB), Awak (ABB) and Nipah (BBB) banana cultivars in Malaysia ranging from 0.09 to $20.47 \mathrm{mg} \mathrm{GAE} / 100 \mathrm{~g}$, in the ripe pulp and peel, respectively. Patthamakanokporn et al. (2008) also observed phenolic contents in the ripe pulp of Namwa cultivar (14 mg GAE / $100 \mathrm{~g}$ ) in Thailand, with lower values when compared to the levels observed in this work. In Malaysia, however, Alothman et al. (2009) obtained average values of 27.0 to 72.2 
mg of GAE / $100 \mathrm{~g}$ for ripe banana pulp (Musa paradisiaca), close to those observed in this study. The different banana cultivars, the ripening stage, as well as the extraction and analysis methods, can contribute to the variation in the contents of phenolic compounds reported.

In literature, higher contents of phenolic compounds are reported in fruit peel than in fruit pulp - as verified in banana (SULAIMAN et al., 2011), mango (KIM et al., 2010), apple (VIEIRA et al., 2009) and tomato (TOOR; SAVAGE, 2005) - and also in this work. Phenolic compounds tend to accumulate in dermal tissues in various plant parts (leaves and fruits), due to their important role in protecting against ultraviolet radiation, acting as attractants in the dispersion of fruits and as defense substances against pathogens, predators and insects (TOOR; SAVAGE, 2005). In apples, Vieira, et al. (2009) observed that mange-resistant cultivars had higher contents of total phenolic compounds in peel compared to susceptible cultivars.

Regarding the color stage, Patthamakanokporn et al. (2008) found in ripe mango, contents of phenolic compounds 1.5 times higher than in the unripe pulp, similar to values observed in this work, both in ripe pulp ripe peel. However, Fatemeh et al. (2012) found that in two banana cultivars in Malaysia, higher contents of phenolic compounds in unripe pulp and peel in relation to these parts when ripe, differing from results found in this study. Kim et al. (2010) reported higher contents of phenolic compounds in the unripe peel in relation to the ripe peel of mango.

\section{Antioxidant activity in pulp and peel}

The variation in the radical removal percentage of fruits is related to the cultivar, the ripening stage and fruit part (pulp and peel). Based on the general average, it is found in banana that the decreasing order of radical removal activity by the DPPH test was as follows: ripe peel $>$ unripe peel $>$ ripe pulp $>$ unripe pulp, suggesting that phenolic compounds may be the major responsible for the antioxidant potential of parts and stages evaluated (Table 3), as observed by Rebello et al. (2014). The antioxidant potential of peel (green and ripe) may also be due to the presence of higher levels of total carotenoids, Vitamin $\mathrm{C}$ and minerals in this fruit part, since these compounds also play an important antioxidant role in fruits.

Unripe banana pulp presented distinct capacity for radical removal in the different cultivars analyzed. 'Terrinha' and 'Ouro' are in the group with the highest percentage of radical removal from extracts; however, Caru-Roxa and Caru-Verde (AAA) were less efficient in the removal of this radical from extracts; therefore, with less antioxidant capacity (Table 3 ). With fruit ripening, a 5\% increase in the radical removal capacity is observed. In ripe banana pulp, 'Ouro' cultivar seemed to be superior to the other cultivars analyzed, presenting $95.36 \%$ of radical removal percentage; therefore, with higher antioxidant potential, while 'Marmelo' was the least efficient in radical removal. In general, ripe pulp presented higher antioxidant potential when compared to unripe pulp, except for 'Nanica', 'Mysore', 'Terrinha', 'Marmelo' and 'Prata-Graúda' cultivars (Table 3 ).

For unripe banana peel, seven groups were formed, with averages ranging from 54.75 to $89.64 \%$, respectively in 'Caipira' (AAA) and 'Mysore' (AAB) cultivars (Table 3 ). In addition, except for 'Ouro', 'Caipira' and 'Caju', in all other cultivars, unripe peel showed greater radical removal capacity, compared to the unripe pulp. With fruit ripening, there was an increase of about $11 \%$ in the antioxidant potential in the ripe fruit peel in relation to the unripe fruit peel. In addition, in ripe banana peel, there was little difference among cultivars, since 10 cultivars belong to the group with the greatest radical removal capacity (Table 3). Comparing only the general averages, ripe peel presents the highest antioxidant potential compared to the other fruit parts and color stages. This demonstrates the great antioxidant potential present in the ripe banana peel because, even using half of the extract aliquot used for the pulp analysis, ripe banana peel presented higher radical removal capacity compared to pulp (Table 3). Fatemeh et al. (2012) also observed higher radical removal capacity in peel in both cultivars evaluated (Cavendish and Dream, Malaysia). However, these authors reported that unripe peel and pulp showed greater elimination capacity than ripe parts. González-Montelongo et al. (2010) observed no differences in the radical removal capacity in the ripe peel of 'Grande Naine' and 'Gruesa' cultivars, both AAA, in Spain.

Fatemeh et al. (2012) reported, for Cavendish and Dream cultivars in Malaysia, average radical removal capacity ranging from 26 to $52 \%$ for ripe pulp and unripe peel, respectively. Shian et al. (2012), also in Malásia, found percentages ranging from 3.2 to $63.1 \%$ in the ripe pulp of 'Berangan' (AA), 'Mas' (AA) and 'Raja' (ABB) bananas. This fact indicates that the antioxidant compounds may vary in the different contents of antioxidant compounds, depending on the cultivar, rioening stage, fruit part, management conditions and the growing region.

The concentration of phenolic compounds, 
carotenoids, vitamin $\mathrm{C}$ and minerals $(\mathrm{Cu}, \mathrm{Zn}, \mathrm{Fe}$, $\mathrm{Mn}$ and Se) plays an important role in fruits. These compounds, in addition to other functions, intercept free radicals generated by the cellular metabolism or by exogenous sources, preventing their harmful action on several molecules of the organism, avoiding the loss of cell integrity. The high antioxidant capacity of banana (pulp and peel) may indicate its important role in the prediction of lipid peroxidation in these fruits (GONZÁLEZ-MONTELONGO et al., 2010).
Banana peel presents great potential for use in human food due to the presence of carbohydrates, phenolic compounds and antioxidant action. The use of unripe and ripe banana peels includes the production of flour, to be added in products such as cupcake, cakes and the like, and can be offered to consumers, presenting a good possibility of industrialization (ALKARKHI et al., 2011). In addition, banana peel can be used in the manufacture of banana sweet, with incorporation of $20 \%$ of peel along with pulp (OLIVEIRA et al., 2009).

TABLE 1 - Average percentage of total soluble sugars (TSS), reducing sugars (RS), non-reducing sugars (NRS) and starch based on fresh matter and respective variation coefficients (VC\%) of the unripe and ripe pulp of 15 bananas cultivars grown in Viçosa, Minas Gerais.

\begin{tabular}{|c|c|c|c|c|c|c|c|c|}
\hline \multirow{2}{*}{ Cultivar } & \multicolumn{2}{|c|}{ TSS } & \multicolumn{2}{|c|}{$\mathrm{RS}$} & \multicolumn{2}{|c|}{ NRS } & \multicolumn{2}{|c|}{ Starch } \\
\hline & Unripe & Ripe & Unripe & Ripe & Unripe & Ripe & Unripe & Ripe \\
\hline & & & & ----- & ---- \% & - & - & ------- \\
\hline Ouro & $0.29 \mathrm{~d}$ & $21.73 a$ & $0.11 \mathrm{c}$ & $11.27 \mathrm{~b}$ & $0.17 \mathrm{c}$ & $10.45 d$ & $21.52 \mathrm{e}$ & $4.51 \mathrm{~d}$ \\
\hline Nanica & $0.36 \mathrm{~d}$ & $22.45 a$ & $0.07 \mathrm{c}$ & $5.06 \mathrm{f}$ & $0.22 b$ & $18.39 \mathrm{a}$ & $22.08 \mathrm{~d}$ & $0.56 \mathrm{f}$ \\
\hline Nanicão & $0.38 \mathrm{~d}$ & $22.17 \mathrm{a}$ & $0.12 \mathrm{c}$ & $11.77 \mathrm{a}$ & $0.17 \mathrm{c}$ & $10.39 \mathrm{~d}$ & $21.08 \mathrm{e}$ & $0.30 \mathrm{f}$ \\
\hline Caru-Verde & $0.35 \mathrm{c}$ & $16.77 \mathrm{c}$ & $0.16 \mathrm{c}$ & $4.4 \mathrm{f}$ & $0.18 \mathrm{c}$ & $12.30 \mathrm{c}$ & $26.18 b$ & $2.97 \mathrm{e}$ \\
\hline Caru-Roxa & $0.61 \mathrm{a}$ & $21.51 \mathrm{a}$ & $0.26 \mathrm{~b}$ & $11.83 \mathrm{a}$ & $0.35 a$ & $9.68 \mathrm{~d}$ & $21.21 \mathrm{e}$ & $3.22 \mathrm{e}$ \\
\hline Caipira & $0.34 \mathrm{c}$ & $18.18 \mathrm{~b}$ & $0.06 \mathrm{c}$ & $4.18 \mathrm{f}$ & $0.27 \mathrm{~b}$ & $13.99 \mathrm{~b}$ & $16.09 \mathrm{f}$ & $3.26 \mathrm{e}$ \\
\hline Prata & $0.37 \mathrm{c}$ & $22.55 \mathrm{a}$ & $0.32 \mathrm{a}$ & $4.94 f$ & $0.05 d$ & $17.61 \mathrm{a}$ & $26.37 b$ & $5.55 \mathrm{c}$ \\
\hline Prata-Anã & $0.38 \mathrm{c}$ & $23.06 \mathrm{a}$ & $0.32 \mathrm{a}$ & $10.68 b$ & $0.05 d$ & $12.38 \mathrm{c}$ & $25.29 b$ & $2.85 \mathrm{e}$ \\
\hline Maçã & $0.27 \mathrm{~d}$ & $17.28 \mathrm{c}$ & $0.11 \mathrm{c}$ & $9.78 \mathrm{c}$ & $0.16 \mathrm{c}$ & $7.49 \mathrm{e}$ & $25.81 \mathrm{~b}$ & $5.68 \mathrm{c}$ \\
\hline Mysore & $0.50 \mathrm{~b}$ & $22.50 \mathrm{a}$ & $0.39 \mathrm{a}$ & $12.58 \mathrm{a}$ & $0.11 \mathrm{~d}$ & $9.91 \mathrm{~d}$ & $22.89 d$ & $0.84 \mathrm{f}$ \\
\hline Pacovan & $0.32 \mathrm{~d}$ & $22.55 \mathrm{a}$ & $0.23 b$ & $11.18 \mathrm{~b}$ & $0.08 \mathrm{~d}$ & $11.37 \mathrm{c}$ & $22.66 \mathrm{~d}$ & $3.85 \mathrm{e}$ \\
\hline Terrinha & $0.53 \mathrm{~b}$ & $10.90 \mathrm{~d}$ & $0.36 \mathrm{a}$ & $10.47 \mathrm{~b}$ & $0.16 \mathrm{c}$ & $0.43 \mathrm{f}$ & $29.16 \mathrm{a}$ & $12.60 \mathrm{~b}$ \\
\hline Marmelo & $0.43 c$ & $11.50 \mathrm{~d}$ & $0.15 \mathrm{c}$ & $11.21 \mathrm{~b}$ & $0.27 \mathrm{~b}$ & $0.29 f$ & $27.93 \mathrm{a}$ & $13.33 \mathrm{a}$ \\
\hline Prata-Graúda & $0.34 \mathrm{c}$ & $18.69 \mathrm{~b}$ & $0.23 \mathrm{a}$ & $7.66 \mathrm{e}$ & $0.10 \mathrm{~d}$ & $11.03 \mathrm{c}$ & $24.16 \mathrm{c}$ & $0.85 f$ \\
\hline Caju & $0.62 \mathrm{a}$ & $19.62 b$ & $0.25 b$ & $8.48 \mathrm{~d}$ & $0.36 \mathrm{a}$ & $11.14 \mathrm{c}$ & $24.10 \mathrm{c}$ & $3.35 \mathrm{e}$ \\
\hline Mean & 0.40 & 19.50 & 0.21 & 9.04 & 0.185 & 10.45 & 23.72 & 4.25 \\
\hline VC (\%) & 10.69 & 4.00 & 20.55 & 7.03 & 21.35 & 10.01 & 3.49 & 8.26 \\
\hline
\end{tabular}

Means followed by the same letter in columns belong to the same group by the Scott-Knott criterion $(\mathrm{p}<0.01)$. 
TABLE 2 - Average percentage of total soluble sugars (TSS), reducing sugars (RS), non-reducing sugars (NRS) and starch based on fresh matter and respective variation coefficients (VC\%) of the unripe and ripe peel of 15 bananas cultivars grown in Viçosa, Minas Gerais.

\begin{tabular}{|c|c|c|c|c|c|c|c|c|}
\hline \multirow{2}{*}{ Cultivar } & \multicolumn{2}{|c|}{ TSS } & \multicolumn{2}{|c|}{ RS } & \multicolumn{2}{|c|}{ NRS } & \multicolumn{2}{|c|}{ Starch } \\
\hline & Ripe & Unripe & Ripe & Unripe & Ripe & Unripe & Ripe & Unripe \\
\hline & & & & & 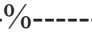 & & & -- \\
\hline Ouro & $0.21 \mathrm{a}$ & $4.26 \mathrm{~d}$ & $0.11 \mathrm{c}$ & $1.84 \mathrm{e}$ & $0.19 b$ & $2.41 d$ & $6.00 \mathrm{e}$ & $1.43 \mathrm{c}$ \\
\hline Nanica & $0.16 \mathrm{~b}$ & $6.36 \mathrm{~b}$ & $0.11 \mathrm{c}$ & $2.89 \mathrm{c}$ & $0.05 \mathrm{c}$ & $3.47 \mathrm{c}$ & $5.18 \mathrm{f}$ & $0.34 d$ \\
\hline Nanicão & $0.23 \mathrm{a}$ & $5.41 \mathrm{c}$ & $0.10 \mathrm{c}$ & $2.29 \mathrm{~d}$ & $0.13 \mathrm{a}$ & $3.11 \mathrm{c}$ & $5.83 \mathrm{e}$ & $0.51 d$ \\
\hline Caru-Verde & $0.16 \mathrm{~b}$ & $6.17 b$ & $0.09 \mathrm{c}$ & $2.70 \mathrm{c}$ & $0.06 \mathrm{~b}$ & $3.47 \mathrm{c}$ & $7.64 d$ & $0.55 \mathrm{~d}$ \\
\hline Caru-Roxa & $0.15 b$ & $6.13 b$ & $0.11 \mathrm{c}$ & $2.01 \mathrm{~d}$ & $0.04 \mathrm{c}$ & $4.12 b$ & $7.21 \mathrm{~d}$ & $0.59 \mathrm{~d}$ \\
\hline Caipira & $0.15 b$ & $2.03 \mathrm{e}$ & $0.11 \mathrm{c}$ & $1.13 \mathrm{e}$ & $0.04 \mathrm{c}$ & $0.89 \mathrm{e}$ & $4.07 f$ & $0.52 \mathrm{~d}$ \\
\hline Prata & $0.19 \mathrm{a}$ & $4.05 \mathrm{~d}$ & $0.12 \mathrm{c}$ & $1.39 \mathrm{e}$ & $0.07 \mathrm{~b}$ & $0.56 \mathrm{e}$ & $5.44 \mathrm{e}$ & $0.60 \mathrm{~d}$ \\
\hline Prata-Anã & $0.23 \mathrm{a}$ & $3.96 \mathrm{~d}$ & $0.17 \mathrm{~b}$ & $3.41 \mathrm{~b}$ & $0.06 \mathrm{c}$ & $0.55 \mathrm{e}$ & $5.75 \mathrm{e}$ & $0.59 \mathrm{~d}$ \\
\hline Maçã & $0.22 \mathrm{a}$ & $7.66 \mathrm{a}$ & $0.17 b$ & $1.41 \mathrm{e}$ & $0.05 \mathrm{c}$ & $6.25 \mathrm{a}$ & $11.26 \mathrm{~b}$ & $1.50 \mathrm{c}$ \\
\hline Mysore & $0.23 \mathrm{a}$ & $6.21 \mathrm{~b}$ & $0.21 \mathrm{a}$ & $3.47 b$ & $0.02 \mathrm{~d}$ & $2.74 d$ & $7.04 \mathrm{~d}$ & $0.54 d$ \\
\hline Pacovan & $0.22 \mathrm{a}$ & $3.16 \mathrm{e}$ & $0.19 \mathrm{a}$ & $2.49 \mathrm{c}$ & $0.03 d$ & $0.33 \mathrm{e}$ & $5.36 \mathrm{e}$ & $1.46 \mathrm{c}$ \\
\hline Terrinha & $0.18 b$ & $4.34 \mathrm{~d}$ & $0.15 b$ & $2.07 \mathrm{~d}$ & $0.02 \mathrm{~d}$ & $2.27 d$ & $7.61 d$ & $1.97 \mathrm{~b}$ \\
\hline Marmelo & $0.14 b$ & $5.21 \mathrm{c}$ & $0.12 \mathrm{c}$ & $4.65 \mathrm{a}$ & $0.01 d$ & $0.76 \mathrm{e}$ & $12.69 \mathrm{a}$ & $2.66 \mathrm{a}$ \\
\hline Prata-Graúda & $0.16 \mathrm{~b}$ & $2.36 \mathrm{e}$ & $0.14 \mathrm{~b}$ & $1.69 \mathrm{e}$ & $0.01 d$ & $0.67 \mathrm{e}$ & $4.78 \mathrm{f}$ & $0.69 \mathrm{~d}$ \\
\hline Caju & $0.14 b$ & $5.15 \mathrm{c}$ & $0.13 \mathrm{c}$ & $4.44 \mathrm{a}$ & $0.01 d$ & $0.50 \mathrm{e}$ & $9.60 \mathrm{c}$ & $1.26 \mathrm{c}$ \\
\hline Média & 0.18 & 4.67 & 0.13 & 2.52 & 0.056 & 2.14 & 7.16 & 1.04 \\
\hline VC $(\%)$ & 10.67 & 8.80 & 11.87 & 11.65 & 35.59 & 13.48 & 7.61 & 12.98 \\
\hline
\end{tabular}

Means followed by the same letter in columns belong to the same group by the Scott-Knott criterion $(\mathrm{p}<0.01)$.

TABLE 3 - Mean values of phenolic compounds (mg GAE), mean radical removal percentage (DPPH) and respective variation coefficients ( $\mathrm{VC} \%)$ in pulp and bark at both ripening stages of the fruits of 15 bananas cultivars grown in Viçosa, Minas Gerais.

\begin{tabular}{lcccc|cccc}
\hline \multirow{2}{*}{ Cultivar } & \multicolumn{3}{c|}{ Total phenolic compounds (mg GAE) } & \multicolumn{3}{c}{ Radical removal percentage (\%) } \\
\cline { 2 - 9 } & \multicolumn{2}{c}{ Pulp } & \multicolumn{2}{c}{ Peel } & \multicolumn{3}{c}{ Pulp } & \multicolumn{2}{c}{ Peel } \\
\cline { 2 - 9 } & Unripe & Ripe & Unripe & Ripe & Unripe & Ripe & Unripe & Ripe \\
\hline Ouro & $27.98 \mathrm{~b}$ & $73.28 \mathrm{a}$ & $29.02 \mathrm{~g}$ & $78.98 \mathrm{e}$ & $88.50 \mathrm{a}$ & $95.36 \mathrm{a}$ & $65.31 \mathrm{e}$ & $86.66 \mathrm{~b}$ \\
Nanica & $25.91 \mathrm{~b}$ & $47.79 \mathrm{~d}$ & $39.33 \mathrm{~d}$ & $104.73 \mathrm{~b}$ & $71.36 \mathrm{~b}$ & $62.61 \mathrm{~g}$ & $89.36 \mathrm{a}$ & $87.59 \mathrm{~b}$ \\
Nanicão & $26.56 \mathrm{~b}$ & $48.62 \mathrm{~d}$ & $48.16 \mathrm{~b}$ & $107.83 \mathrm{~b}$ & $66.72 \mathrm{c}$ & $69.44 \mathrm{e}$ & $85.28 \mathrm{~b}$ & $87.96 \mathrm{~b}$ \\
Caru-Verde & $23.15 \mathrm{c}$ & $42.39 \mathrm{~d}$ & $43.37 \mathrm{c}$ & $81.76 \mathrm{~d}$ & $52.07 \mathrm{e}$ & $65.63 \mathrm{f}$ & $88.88 \mathrm{a}$ & $89.56 \mathrm{a}$ \\
Caru-Roxa & $28.05 \mathrm{~b}$ & $42.87 \mathrm{~d}$ & $41.77 \mathrm{c}$ & $72.79 \mathrm{f}$ & $53.76 \mathrm{e}$ & $72.69 \mathrm{~d}$ & $89.18 \mathrm{a}$ & $90.01 \mathrm{a}$ \\
Caipira & $24.62 \mathrm{c}$ & $66.08 \mathrm{~b}$ & $32.07 \mathrm{f}$ & $76.69 \mathrm{e}$ & $63.34 \mathrm{~d}$ & $79.85 \mathrm{c}$ & $54.75 \mathrm{~g}$ & $88.77 \mathrm{a}$ \\
Prata & $24.48 \mathrm{c}$ & $59.48 \mathrm{c}$ & $35.02 \mathrm{e}$ & $88.02 \mathrm{c}$ & $58.90 \mathrm{~d}$ & $63.08 \mathrm{~g}$ & $76.54 \mathrm{c}$ & $90.04 \mathrm{a}$ \\
Prata-Anã & $28.00 \mathrm{~b}$ & $52.68 \mathrm{c}$ & $38.15 \mathrm{~d}$ & $87.95 \mathrm{c}$ & $61.80 \mathrm{~d}$ & $65.17 \mathrm{f}$ & $74.16 \mathrm{c}$ & $90.22 \mathrm{a}$ \\
Maçã & $26.77 \mathrm{~b}$ & $50.74 \mathrm{c}$ & $40.97 \mathrm{c}$ & $108.46 \mathrm{~b}$ & $59.35 \mathrm{~d}$ & $66.70 \mathrm{f}$ & $85.81 \mathrm{~b}$ & $89.39 \mathrm{a}$ \\
Mysore & $27.76 \mathrm{~b}$ & $50.22 \mathrm{c}$ & $40.97 \mathrm{c}$ & $82.91 \mathrm{~d}$ & $64.91 \mathrm{c}$ & $61.06 \mathrm{~h}$ & $89.64 \mathrm{a}$ & $89.90 \mathrm{a}$ \\
Pacovan & $26.25 \mathrm{~b}$ & $53.27 \mathrm{c}$ & $37.57 \mathrm{~d}$ & $73.77 \mathrm{f}$ & $60.75 \mathrm{~d}$ & $73.76 \mathrm{~d}$ & $75.32 \mathrm{c}$ & $90.24 \mathrm{a}$ \\
Terrinha & $33.28 \mathrm{a}$ & $77.07 \mathrm{a}$ & $61.00 \mathrm{a}$ & $115.70 \mathrm{a}$ & $88.57 \mathrm{a}$ & $85.21 \mathrm{~b}$ & $89.52 \mathrm{a}$ & $90.38 \mathrm{a}$ \\
Marmelo & $31.56 \mathrm{a}$ & $50.28 \mathrm{c}$ & $36.42 \mathrm{e}$ & $60.39 \mathrm{~h}$ & $61.76 \mathrm{~d}$ & $44.41 \mathrm{i}$ & $71.45 \mathrm{~d}$ & $69.40 \mathrm{c}$ \\
Prata-Graúda & $23.87 \mathrm{c}$ & $53.88 \mathrm{c}$ & $39.72 \mathrm{~d}$ & $86.50 \mathrm{c}$ & $60.82 \mathrm{~d}$ & $58.35 \mathrm{~h}$ & $85.98 \mathrm{~b}$ & $90.24 \mathrm{a}$ \\
Caju & $27.11 \mathrm{~b}$ & $54.63 \mathrm{c}$ & $36.03 \mathrm{e}$ & $66.73 \mathrm{~g}$ & $61.47 \mathrm{~d}$ & $63.28 \mathrm{~g}$ & $60.66 \mathrm{f}$ & $86.83 \mathrm{~b}$ \\
Médias & 27.02 & 54.88 & 39.97 & 86.21 & 64.93 & 68.44 & 78.78 & 87.81 \\
VC (\%) & 5.55 & 6.67 & 3.97 & 2.49 & 3.33 & 2.66 & 2.12 & 1.18 \\
\hline
\end{tabular}

Means followed by the same letter in columns belong to the same group by the Scott-Knott criterion $(\mathrm{p}<0.01)$. 


\section{CONCLUSIONS}

Cultivar, as well as ripening stage, influences the levels of total soluble sugars, reducing sugars, non - reducing sugars, starch, total phenolics and antioxidant potential of banana pulp and peel. Fruits of Terrinha, Marmelo, Maçã, Ouro and Caru-Verde cultivars stand out for their highest contents of carbohydrates, phenolic compounds and antioxidant action. Terrinha and Marmelo cultivars presented high predominance of reducing sugars, in relation to the non - reducing sugars, in the ripe pulp. Cultivars of $\mathrm{AAB}$ and $\mathrm{ABB}$ genomic groups presented higher starch content compared to cultivars of AA and AAA groups. Ripe peel has higher antioxidant potential, being three times greater than that present in the unripe pulp.

\section{ACKNOWLEDGEMENTS}

To the National Council for Scientific and Technological Development (CNPq), for the financial support and granting of scholarships to the authors.

\section{REFERENCES}

ABDEL-HAMEED, E.S.S. Total phenolic contents and free radical scavenging activity of certain Egyptian Ficus species leaf samples. Food Chemistry, London, v.114, n.4, p.1271-1277, 2009.

ALKARKHI, A.F.M.; RAMLI, S.B.; YONG, Y.S.; EASA, A.M. Comparing physicochemical properties of banana pulp and peel flours prepared from green and ripe fruits. Food Chemistry, London, v.129, n.2, p.312-318, 2011.

ALOTHMAN, M.; BHAT, R.; KARIM, A.A. Antioxidant capacity and phenolic content of selected tropical fruits from Malaysia, extracted with different solvents. Food Chemistry, London, v.115, n.3, p.785-788, 2009.

BLOIS, M.S. Antioxidant determinations by the use of a stable free radical. Nature, London, v.181, p. 1199-1200, 1958.

BLOOR, S. Overview of methods for analysis and identification of flavonoids. Methods in Enzymology, Amsterdam, v.335, p.3-14, 2001.
CHITARRA, M.I.F.; CHITARRA, A.B. Pós-colheita de frutos e hortaliças: fisiologia e manuseio. 2.ed. Lavras, MG: UFLA, 2005. 785 p.

DADZIE, B. K.; ORCHARD, J. E. Evaluación rutinaria postcosecha de híbridos de bananos y plátanos: critérios y métodos. Montpelier: INIBAP, 1997. 63 p. (Guias técnicas Inibap, 2).

EMAGA, T.H.; ANDRIANAIVO, R.H.; WATHELET, B.; TCHANGO, J.T.; PAQUOT, M. Effects of the stage of maturation and varieties on the chemical composition of banana and plantain peels. Food Chemistry, London, v.103, p. 590-600, 2007.

FATEMEH, S.R.; SAIFULLAH, R.; ABBAS, F.M.A.; AZHAR, M.E. Total phenolics, flavonoids and antioxidant activity of banana pulp and peel flours: influence of variety and stage of ripeness. International Food Research Journal, Serdang, v.19, n.3, p.1041-1046, 2012.

GONZÁLEZ-MONTELONGO, R.; LOBO, M.G.; GONZÁLEZ, M. Antioxidant activity in banana peel extracts: Testing extraction conditions and related bioactive compounds. Food Chemistry, London, v.119, n.3, p.1030-1039, 2010.

HODGE, J.E.; HOFREITER, B.T. Determination of reducing sugars and carbohydrates. In: WHISTLER, R. L.; WOLFROM, M. L. (Ed.). Methods in carbohydrates chemistry. New York: Academic Press, 1962. v.1, p.380-394.

ISABELLE, M.; LEE, B.L.; LIM, M.T.; KOH, W.P.; HUANG, D.; ONG, C.N. Antioxidant activity and profiles of common fruits in Singapore. Food Chemistry, London, v.123, n.1, p.77-84, 2010.

JESUS, S.C.; FOLEGATTI, M.I.S.; MATSUURA, F.C.A.U.; CARDOSO, R.L. Caracterização física e química de frutos de diferentes genótipos de bananeira. Bragantia, Campinas, v.63, n.3, p.315323, 2004.

JUAREZ-GARCIA, E.; AGAMA-ACEVEDO, E.; YAGO-AYERDI, S.G.; RODRÍGUEZ-AMBRIZ, S.L.; BELLO-PÉREZ, L.A. Composition, digestibility and application in breadmaking of banana flour. Plant Foods for Human Nutrition, New York, v.61, p.131-137, 2006.

KIM, H.; MOON, J.Y.; KIM, H.; LEE, D.S.; CHO, 
M.; CHO, H.K.; KIM, Y.S.; MOSADDIK, A.; CHO, S.K. Antioxidant and antiproliferative activities of mango (Mangifera indica L.) flesh and peel. Food Chemistry, London, v.121, n.2 p.429-436, 2010.

LEONEL, M.; CARMO, E.L.; LEONEL, S.; FRANCO, C.M.L.; CAMPANHA, R.B. Extração e caracterização do amido de diferentes genótipos de bananeira. Revista Brasileira de Fruticultura, Jaboticabal, v.33, n.1, p.599-605, 2011. Número Especial.

LICHTEMBERG, L.A. Colheita e pós-colheita da banana. Informe Agropecuário, Belo Horizonte, v.20, n.196, p.73-90, 1999.

McCREADY, R.M.; GUGGOLZ, J.; SILVIERA, V.; OWENS, H.S. Determination of starch and amylose in vegetables: Application in Peas. Analytical Chemistry, Washington, v.22, n.9, p.1156-1158, 1950.

MOTA, R.V.; LAJOLO, F.M.; CORDENUNSI, B.R. Composição em carboidratos de alguns cultivares de banana (Musa spp.) durante o amadurecimento. Ciência e Tecnologia de Alimentos, Campinas, v.17, n.2, p.94-97, 1997.

NELSON, N. A photometric adaptation of the Somogy method for the determination of glucose. Journal of Biological Chemistry, Rockville, v.153, p.375-380, 1944.

OLIVEIRA, D.A.S.B.; MÜLLER, P.S.; FRANCO, KOTOVICZ V.; WASZCZYNSKYJ, N. Avaliação da qualidade de pão com adição de farinha e purê da banana verde. Revista Brasileira de Fruticultura, Jaboticabal, v.37, n.3, p.699-707, 2015.

OLIVEIRA, L.F.; BORGES, S.V.; NASCIMENTO, J.; CUNHA, A.C.; JESUS, T.B.; PEREIRA, P.A.P.; PEREIRA, A.G.T.; FIGUEIREDO, L.P.; VALENTE, W.A. Utilização de casca de banana na fabricação de doces de banana em massa - avaliação da qualidade. Alimentos e Nutrição, Araraquara, v.20, n.4, p.581$589,2009$.

PATEL, R.Z. A note on the seasonal variations in starch content of different parts of coffea Arabica trees. East African Agricultural and Forestry Journal, Nairobi, v.36, n.1, p.1-4, 1970.

PATTHAMAKANOKPORN, O.; PUWASTEIEN,
P.; NITITHAMYONG, A.; SIRICHAKWAL, P.P. Changes of antioxidant activity and total phenolic compounds during storage of selected fruits. Journal of Food Composition and Analysis, Oxford, v.21, n.3, p.241-248, 2008.

REBELLO, L.P.G.; RAMOS, A.M.; PERTUZATTI, P.B.; BARCIA, M.T.; CASTILLO-MUNÕZ, N.; HERMOSÍN-GUTIÉRREZ, I. Flour of banana (Musa AAA) peel as a source of antioxidant phenolic compounds. Food Research International, New York, v.55, p.397-403, 2014.

RODRÍGUEZ-A MBRIZ，S.L.; ISLASHERNÁNDEZ, J.J.; AGAMA-ACEVEDO, E.; TOVAR, J.; BELLO-PÉREZ, L.A. Characterization of a fibre-rich powder prepared by liquefaction of unripe banana flour. Food Chemistry, London, v.107, n.4, p.1515-1521, 2008.

SHIAN, T.E.; ABDULLIAH, A.; MUSA, K.H.; MASKAT, M.Y.; GHANI, M.A. Antioxidant properties of three banana cultivars (Musa acuminata 'Berangan', 'Mas' and 'Raja') Extracts. Sains Malaysiana, Bangi, v.41, n.3, p.319-324, 2012.

SILVA, P.S.L.; MENEZESS, J.B.; OLIVEIRA, O.F.; SILVA, P.L.B. Distribuição do teor de sólidos solúveis totais no melão. Horticultura Brasileira, Brasília, DF, v.21, n.1, p.31-33, 2003.

SINGLETON, V.L.; ORTHOFER, R.; LAMAUELARAVENTÓS, R.M. Analysis of total phenols and other oxidation substrates and antioxidantes by means of folin-ciocalteu reagent. Methods in Enzymology, Amsterdam, v.299, p.152-178, 1999.

SOMOGYI, M. Notes on sugar determination. The Journal of Biological Chemistry, Rockville, v.95, p.19-23, 1952.

SULAIMAN, S.F.; YUSOFF, N.A.M.; ELDEEN, I.M.; SEOW, E.M.; SAJAK, A.A.; SUPRIATNO, B.; OOI, K.L. Correlation between total phenolic and mineral contents with antioxidant activity of eight Malaysian bananas (Musa sp.). Journal of Food Composition and Analysis, Oxford, v.24, n.1, p.1-10, 2011.

TOOR, R.K.; SAVAGE, G.P. Antioxidant activity in different fractions of tomatoes. Food Research International, Toronto, v.38, n.5, p.487-494, 2005.

VERGARA-VALENCIA, N.; GRANADOS-PÉREZ, 
E.; AGAMA-ACEVEDO, E.; TOVAR, J.; RUALES, J.; BELLO-PÉREZ, L.A. Fibre concentrate from mango fruit: Characterization, associated antioxidant capacity and application as a bakery product ingredient. LWT - Food Science and Technology, Amsterdam, v.40, n.4, p.722-729, 2007.

VIEIRA, F.G.K.; BORGES, G.S.C.; COPETTI, C.; GONZAGA, L.V.; NUNES, E.C.; FETT, R. Activity and contents of polyphenolic antioxidants in the whole fruit, flesh and peel of three apple cultivars. Archivos Latinoamericanos de Nutricion, Caracas, v.59, n.1, p.101-106, 2009.
ZHANG, P.; WHISTLER, R.L.; BEMILLER, J.N.; HAMKER, B.R. Banana starch: production, physicochemical properties, and digestibility-a review. Carbohydrate Polymers, Amsterdam, v.59, n.4, p.443-458, 2005. 